EPiC Series in Computing
Volume 52, 2018, Pages 153-167
$\begin{aligned} & \text { ICT4S2018. 5th International Conference on Informa- } \\ & \text { tion and Communication Technology for Sustainability }\end{aligned}$

\title{
A Comparative Analysis of Green ICT Maturity Models
}

\author{
David Lautenschutz ${ }^{1}$, Sergio España ${ }^{2}$, Albert Hankel $^{3,4}$, Sietse Overbeek ${ }^{2}$ and Patricia Lago ${ }^{4}$ \\ ${ }^{1}$ Ministry of the Interior and Kingdom Relations, Government of the Netherlands, the Hague, the \\ Netherlands \\ david.lautenschutz@minbzk.nl \\ ${ }^{2}$ Department of Information and Computing Sciences, Utrecht University, Utrecht, the Netherlands \\ \{s.espana,s.j.overbeek\}@uu.nl \\ ${ }^{3}$ SURFnet, Utrecht, the Netherlands \\ albert.hankel@surfnet.nl \\ ${ }^{4}$ Department of Computer Science, Vrije Universiteit Amsterdam, Amsterdam, the Netherlands \\ \{a.c.hankel,p.lago\}@vu.nl
}

\begin{abstract}
Maturity models have become a common tool for organisations to assess their capabilities in a variety of domains. However, for fields that have not yet been researched thoroughly, it can be difficult to create and evolve a maturity model that features all the important aspects in that field. It takes time and many iterative improvements for a maturity model to come of age. This is the case for Green ICT maturity models, whose aim is typically to either provide insight on the important aspects an organisation or a researcher should take into account when trying to improve the social or environmental impact of ICT, or to assist in the auditing of such aspects. In fact, when we were commissioned a comprehensive ICT-sustainability auditing for Utrecht University, we not only faced the need of selecting a Green ICT maturity model, but also to ensure that it covered as many organisational aspects as possible, extending the model if needed. This paper reports on the comparison we carried out of several Green ICT maturity models, how we extended our preferred model with needed constructs, and how we applied the resulting model during the ICT-sustainability auditing.
\end{abstract}

Keywords: Comparative analysis, Green ICT, ICT sustainability, maturity model, qualitative content analysis.

\section{Introduction}

Organisations evolve under constant pressure to improve their performance, as well as to gain and retain competitive advantage. Nowadays, maturity models are a common tool that organisations use to assess their maturity in a specific domain and guide their continuous improvement processes. Maturity models are conceptual models based on the idea that organisational capabilities develop through a sequence of anticipated, desired or logical stages from an initial to a more mature state [9]. The basic components of a maturity model are (i) a number of maturity levels, (ii) a 
set of dimensions, aspects, concepts, key process areas or functional areas (we will refer to them as constructs) that can be developed along a predefined evolutionary path to achieve the defined maturity levels, and (iii) descriptions of each step on the path typically consisting of guidelines, key processes or best practices [33].

The introduction of the Capability Maturity Model (CMM) by the Software Engineering Institute was a major milestone for the widespread use of maturity models [5]. Fields such as software development, business process management, knowledge management and project management have well-established maturity models [5][14][15][16][18][34].

De Bruin et al. [5] discuss important aspects related to the development of maturity models; e.g. deciding what the maturity model should assess and which constructs are to be included in this model. Furthermore, they describe how one can choose and specify the constructs using an extensive literature search. However, in nascent areas, the available literature is scarce and often inconsistent, so collecting these constructs to develop a complete and accurate maturity model can turn out to be problematic. This is precisely the case for Green ICT [22], understood as the scientific and engineering area that covers the environmental impact of information and communication technology (ICT) as well as the use of ICT tools, services and technologies to stimulate green practices and green behaviour [10], and to contribute to the enhancement of the quality of human life [1]. The field is relatively new and is still consolidating the maturity models.

A maturity model in the context of Green ICT is a framework for systematically assessing and improving sustainable ICT capabilities within organisations [6]. So far, no systematic comparison of the available Green ICT maturity models has been performed. We lack knowledge of the similarities, differences or completeness of the models in this area. The impact of an incomplete maturity model depends on its intended use. For instance, when a company selects a Green ICT maturity model to guide them through the improvement of their ICT sustainability, if the model lacks a construct such as e-waste management, i.e., the responsible disposal of used ICT resources, the company could end up overlooking this practice.

This paper collects and analyses several Green ICT maturity models and conceptual frameworks. For this purpose, we have devised a method that identifies the similarities and differences between the models. Among other comparisons, we map the constructs across the different models. We also report on how we used the gathered knowledge to extend one of the maturity models with some constructs that were needed, so we could later use it during an ICT sustainability auditing conducted in Utrecht University's Information and Technology Services (ITS) department.

Before starting this endeavour, we have reviewed previous efforts to compare maturity models from different fields, in order to learn from the experience of other authors before defining our research method; the results are reported in Section 2. Then, Section 3 presents the research method, where we explain how we have proceeded during this project. In Section 4, we report on the results of the analysis and comparison of Green ICT maturity models. Section 6 discusses how we have improved a maturity model and used it as an auditing tool. We discuss the results in Section 7 , where we also acknowledge some threats to their validity. Finally, we conclude the work in Section 7, pointing out some issues for future research.

\section{On previous comparisons of maturity models}

Some authors have compared maturity models as part of their research projects. Although the domains are distinct to Green ICT, we find it convenient to learn from their experience. Jiankang et al. [15] review 26 knowledge management maturity models. They create tables to map the constructs of each model, which they refer to as key process areas, and the proposed range of maturity levels. Then they discuss the tables and draw conclusions. 
Khoshgoftar and Osman [16] take a different approach in order to compare project management maturity models. The authors specify a list of variables related to project management, although they do not provide a rationale for this selection, and they assess a set of maturity models with respect to them. Eventually, one maturity model is chosen that satisfies the variables the most and is deemed to be the best maturity model. The author specifies several arguments with qualitative motivations on why a specific maturity model is deemed to be the best.

Pulparambi and Baghdadi [30] compare maturity models concentrated on Service Oriented Architecture (SOA). The primary objective of a SOA is to align the gap between business and IT by applying service-oriented design principles. The authors follow a similar approach to the paper by Khosgoftar and Osman; they first gather a large list of constructs that are deemed to be valuable for SOA, such as Value chain, Business process and Governance, and analyse how a collection of SOA maturity models cover and implement these constructs. After the mapping, the authors manually draw a conclusion by discussing the data in the table.

Lee et al. [18] compare two process-maturity models intended to improve organisational process performance. For each model, they analyse four aspects: (i) inputs and philosophies, which refer to the theories and principles underpinning the models, (ii) structural components refers to the number of maturity levels and key process areas, (iii) normative components map the maturity levels of both models, and (iv) informative components map the constructs (referred to as key process areas). For each aspect, the authors discuss the pros and cons of each maturity model and end up selecting one of them.

All papers mentioned above have three similarities. Firstly, the authors define a list of aspects and assess each maturity model with respect to them. The specific aspects differ from paper to paper. Secondly, they produce a mapping of the main constructs of each maturity model. Thirdly, they draw conclusions by performing a qualitative analysis or argumentation on the results of the comparison. We agree that this is a rational approach. However, we also found some common limitations. The comparison approaches are domain-specific, making it difficult to apply in a different domain. Each paper analyses the maturity models at a different level of detail; the aspects seem chosen depending on the purpose of the comparison, sometimes being the confirmation that the maturity model proposed by the authors is superior in some aspect (e.g. [18]) prefer their artefact above the previously existing process maturity model because it includes a value orientation). Although some of the papers mentioned above provide some indication on how the authors analysed the maturity models, none of them explicitly specify the method for performing comparisons of maturity models. Moreover, none of papers address the improvement of a maturity model based on its missing constructs, but rather just determine the most suitable one. As a conclusion, we could learn from the experience of other authors, but we could not reuse a ready-made method to compare maturity models. We instead designed our own.

\section{Research method}

Figure 1 depicts the research method using the Process Deliverable Diagram technique [32]. A process deliverable diagram helps in clarifying the activities within a method and the products involved, in a structured manner. We discussed the trade-offs of the method with other researchers and improved it when necessary.

\subsection{Collect maturity models}

We first conducted a literature review of Green ICT maturity models. The papers presenting the maturity models were retrieved from Google Scholar using a variety of search strings such as "sus- 
tainable ICT maturity model", "green ICT conceptual model", "green IT framework", and hybrids. We applied snowballing sampling when deemed convenient.

We not only collected those that were presenting a Green ICT maturity model, but also Green ICT conceptual frameworks because they also provide a structured set of constructs (for the sake of brevity, we will refer to them also as maturity models). For each maturity model, we acquired the most updated version of the documentation that describes its structure and constructs; even when that required downloading it from a website.

We reviewed the documentation of each model in order to extract the following information:

- Background: General information about the maturity model, such as the authors, and overview.

- Main goal: The aim of the maturity model.

- Theoretical foundation: Why the maturity model has the structure and content as presented. In some occasions, the documentation of the maturity model does not clarify whether the authors based the model in any theory, nor provides any rationale for the design decisions.

- Construct diagram: A diagram showing the constructs of the domain within the maturity model. Maturity models rarely present the constructs as a flat list, but rather structure them as a taxonomy with several levels. Sometimes, the authors of the maturity model have created such a diagram; in other occasions, we had to create it. In some occasions, to fully understand the meaning of constructs, we read related literature further explaining it.

- Application protocol: How the maturity model is to be applied in a practical setting (e.g. whether it only presents an overview of the domain, or it specifies maturity levels as well). We describe the process to apply the model, if any was defined by the authors.

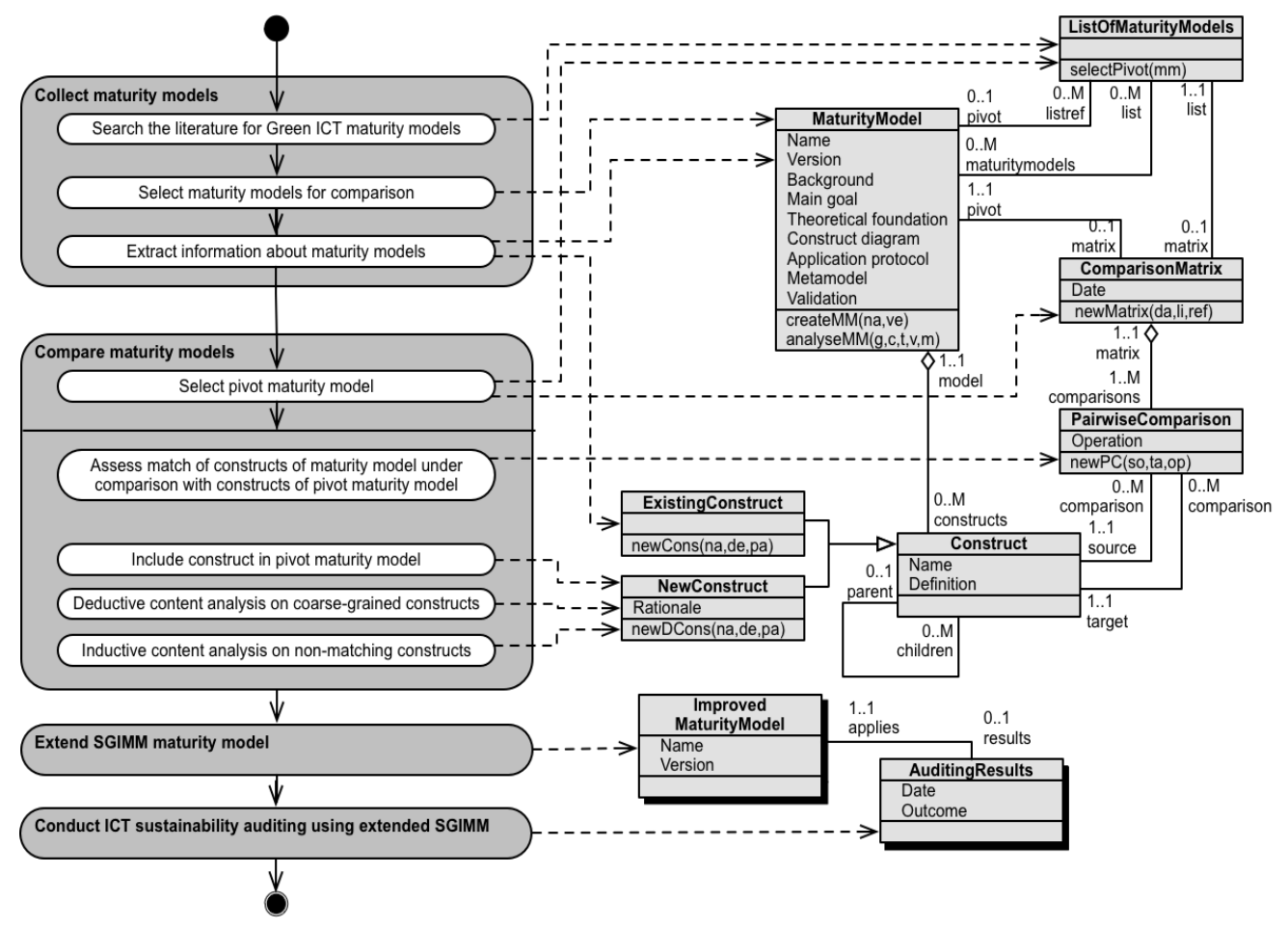

Figure 1. Process deliverable diagram (PDD) of the research method. 
- Metamodel: The underlying structure of the maturity model. It is a generalisation of the construct diagram and it specifies the structure of the taxonomy of constructs. In any case, the metamodel can also contain additional elements if needed. We had to create such metamodel for most cases.

- Validation: Whether any research has been conducted to validate the model as such and its practical benefits.

\subsection{Compare maturity models}

In order to facilitate the comparison and mapping of the constructs within the maturity models, a pivot maturity model is required. Our experience shows that the result of the comparison does not depend on the selection of the pivot, but it determines how the results are presented. We selected the SURF Green ICT Maturity Model (SGIMM) [12] for the convenient reason that the ITS department, who commissioned the authors 1, 2 and 4 the ICT sustainability auditing, had a preference for this maturity model and wanted us to apply it during the auditing. It was after this selection that we engaged in collaboration with authors 3 and 5, two of the original creators of this model.

The comparison is the most crucial and complex stage of the method. Overall it consists of a systematic comparison of the constructs of each maturity model with respect to the constructs of the pivot maturity model. To determine whether two constructs are equivalent and therefore can be mapped, qualitative content analysis is required. Qualitative content analysis allows us comparing constructs from distinct maturity models that do not necessarily have the exact same name or description [8]. It is the concepts behind the construct what is important, as well as the organisational practices that are prescribed in order to increase the maturity of the organisation. Qualitative content analysis has two possible variations; namely deductive and inductive qualitative content analysis [8].

Deductive content analysis is a method for deductive reasoning; that is, going from general to detailed. It is a sort of refinement that can help in determining the similarities between constructs by splitting the general construct into several smaller constructs and attempting to match those.

Inductive content analysis has the opposite direction; that is, going from detailed to general. Such abstraction facilitates identifying the underlying theoretical concept behind a fine-grained construct, or also categorising several constructs.

Since constructs can be decomposed arbitrarily in many finer-grained constructs and also constructs can be increasingly generalised, the level of granularity for the content analysis had to be determined by us during the comparison. Deductive content analysis provides more items for comparison, but also costs more time to execute. When a construct in a model was deemed to be too general it was refined. In the absence of rigorous criteria, our rule of thumb was applying common sense. Inductive content analysis was suited for situations where a construct was so refined in one maturity model that it could be easily mapped to constructs of the pivot maturity model. It was also useful when aggregating several missing constructs of the pivot maturity model into a single one. Beyond that, we avoided applying it for the threat of subjectivity it entails. We provide examples of both types of analysis in section 4 .

While comparing the constructs, a matrix was constructed. This matrix supported the comparison and also served to present the final results. The columns of the matrix are the maturity models being compared. To facilitate the comparison process, the first column corresponds to the pivot model. The upper row contains the names of the maturity models and its constructs are listed in the cells underneath. Two constructs from two maturity models are located in the same row when they are equivalent. A cell of a maturity model can be empty when it misses a construct present in other models. This can be also represented with an X or any other convention. When there is a difference 
in the granularity of the constructs, then the cells from several rows can be merged for the model that contains the most generic construct.

\subsection{Extend SGIMM maturity model}

Since we had to apply the SGIMM maturity model to conduct an ICT sustainability auditing, we took the opportunity to identify the constructs that this model was missing and, when deemed convenient, add them. For this purpose, we first identified which rows of the comparison matrix for which the first cell was empty, i.e., missing constructs. These findings were translated into proposals, since adding a missing construct is potentially an improvement of the pivot maturity model.

Each proposal was discussed within the research team and also with the representatives from the ITS department. We not only took into consideration the constructs themselves, but also whether they fit in the SGIMM maturity model, regarding its goal, level of detail, and structure. Eventually, decisions were made, resulting in a new version of the model, which was fit for its application during the auditing. The Excel-based tool supporting SGIMM was updated accordingly.

\subsection{Conduct ICT sustainability auditing using extended SGIMM}

We developed a protocol for the auditing, applying best practices by Pahuja [27] and also our previous experience. The auditing required several meetings with members of the ITS department. We used the Excel-based tool to support the scoring, calculate the results and produce charts.

\section{Analysis of Green ICT maturity models}

\subsection{Collection of maturity models}

After the literature review and the selection process, we ended up with 7 maturity models and assigned a proper name to those models that missed one: SURF Green ICT Maturity Model (SGIMM) [12], G-Readiness Framework [24], Practice-Oriented Green IS Framework [3], Holistic Approach to Green IT [26], Green IT framework for Greening Data Centers [31], Sustainable ICT Capability Maturity Framework [6] and the Envirability Maturity Framework [29].

We analysed each maturity model separately. The full results can be found in the first author's MSc thesis report [17]. For the sake of brevity, we only include a summary of the information about SGIMM here:

- Background: SGIMM has been developed within SURF, a Dutch organisation focused on developing ICT for educational institutions [12]. The development was triggered by the need of such institutions for a clear framework and examples about Green ICT and a tool that allowed them to determine the maturity level they had. SGIMM is currently supported by an Excelbased tool.

- Main goal: Its intended purpose is to (i) foster an internal dialogue within organisations, (ii) facilitating agreement on diagnosis of the current situation (the overall maturity level), and (iii) defining improvement actions.

- Theoretical foundation: The constructs were defined by a group of Green ICT experts. The authors decided to keep the model simple to facilitate adoption, at the cost of missing some details; completeness was not a major concern. With respect to the maturity levels and application process, this model builds upon the Capability Maturity Model Integration method, which has influenced the proposal of five maturity levels for quality and process improvements [28], as well upon the criteria by Curry and Donnellan that facilitates deciding the maturity level of Green ICT constructs [4]. 


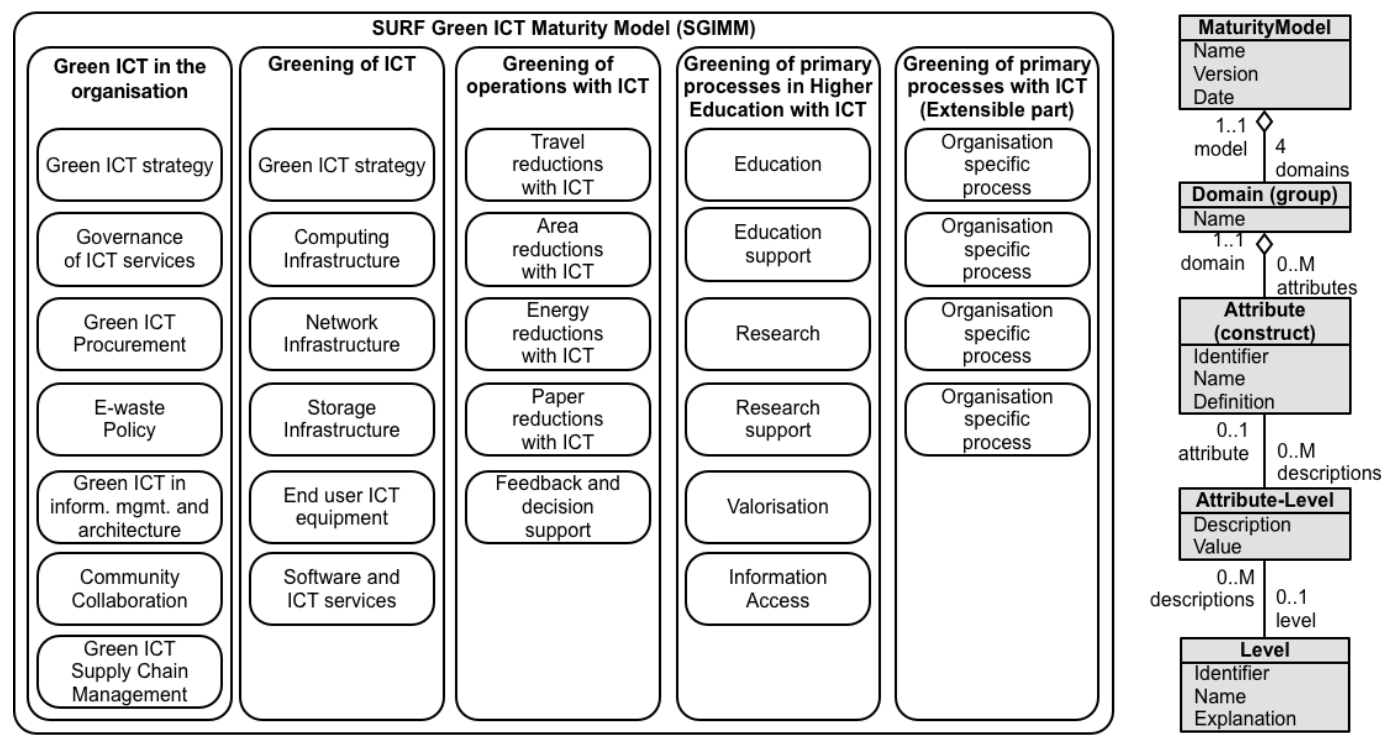

Figure 2. Construct diagram (left-hand side) and metamodel (right-hand side) of SURF Green ICT Maturity Model (SGIMM).

- Construct diagram: Constructs (referred to as attributes in SGIMM) are categorised on 4 groups (referred to as domains): (i) Green ICT in the organization, (ii) Greening of ICT, (iii) Greening of operations with ICT, and (iv) Greening of primary processes with ICT. The first 3 groups are sector-independent and amount to 18 attributes, whereas the fourth is sector-specific. SGIMM proposes 6 sector-specific constructs related to the higher education sector. These are based on the 'Hoger Onderwijs Referentie Architectuur', a Dutch reference architecture for this sector; however, these constructs can be discarded if the organisation belongs to a different sector. It is extensible, so, depending on the needs of the organisation, more attributes can be added. The diagram is shown in the left-hand side of Figure 2.

- Application protocol: An assessment manager triggers the auditing process; typically, this would be a chief information officer or ICT manager. The assessment manager designates an assessment team, who are stakeholders that will use the Excel-based tool to determine the maturity of those attributes within their competence. As indicated above, SGIMM measures the maturity level of each construct on a scale from 1 to 5 . The results are then aggregated, producing a dashboard of radar charts. The assessment manager and team meet to discuss the results and define an improvement action plan. SGIMM provides guidelines for each of these steps.

- Metamodel: The metamodel is presented on the right-hand side of Figure 2. The only input by the users, i.e., members of the assessment team, is the name of the organisation (MaturityModel.Name), the date when they fill the model in (MaturityModel.Date) and the maturity-level score for each construct (Attribute-Level.Value).

- Validation: The taxonomy of constructs was drafted in a workshop with nine Green ICT experts, followed by a survey that resulted in improvements and a pilot test that consolidated the model with minor changes [12]. The benefits for organisations and insights for its stakeholders has been investigated by applying the model to four organisations [11]. 


\subsection{Comparison of maturity models}

Not all the models we analysed have the same goal. All models share the intention to raise awareness and help organisations identify which Green ICT areas they need to improve. However, the models put the emphasis on different aspects. For instance, the Holistic approach to Green IT [26] focuses on showing the interrelation of the different constructs, and offering reference process maps of sustainable ICT lifecycles. Also, they often differ on the application protocol. For instance, G-readiness also calculates the averages for each construct group in order to depict the result as a radar chart. However, instead of CMMI maturity levels used by SGIMM, it offers a survey with statements about the maturity of the organisation in relation to the Green ICT constructs; the user determines the level of agreement using a 7-point Likert scale. The Practice-Oriented Green IS Framework [3] does not offer guidelines for its application but, in turn, distinguishes which constructs apply to organisational actors, e.g., Commitment Mechanisms and which refer to processes, e.g., Waste disposal / Recycling.

With regard to the coverage of constructs of each maturity models, we conducted the comparison following the qualitative content analysis as explained in Section 3.3.2. and taking SGIMM as the pivot model.

As an example of inductive content analysis, some constructs that were found to be missing in the SGIMM were Attitude regarding greenhouse gas (GHG) emissions (contained in [24]), Governance \& Compliance to lower CO2, Carbon Emission Management, and Measure CO2 emissions (the three contained in [31]) and Carbon emission management (in [29]). Such constructs were generalised as GHG emission management. The purpose was to map these constructs better, and to facilitate discussions with stakeholders regarding the value of adding such construct to the SGIMM.

As an example of deductive content analysis, while comparing the G-readiness framework [23] with the SGIMM [12], we found the constructs of the former to be more generic and coarsegrained. Performing deductive content analysis on the G-readiness framework allowed decomposing its constructs based on their descriptions and this provided more items for comparison. Then it became more evident which constructs of the G-readiness framework matched SGIMM constructs and which were missing in SGIMM.

The resulting comparison matrix is presented in 0Two constructs from different models can be considered strongly related when they are located in the same row. The relationship can be manyto-many, as indicated in Figure 1 (see the relationships between the classes Construct and PairwiseComparison). Rows with grey background are categories of constructs within SGIMM and they are predefined in the model; they have also been included for the sake of readability. 
Table 1. Comparison matrix

\begin{tabular}{|c|c|c|c|c|c|c|}
\hline $\begin{array}{l}\text { SURF Green ICT } \\
\text { Maturity Model } \\
{[12]}\end{array}$ & $\begin{array}{l}\text { G-Readiness } \\
\text { framework [24] }\end{array}$ & $\begin{array}{l}\text { Practice orient- } \\
\text { ed Green IS } \\
\text { Framework [3] }\end{array}$ & \begin{tabular}{|l|} 
Holistic \\
approach to \\
Green IT [26]
\end{tabular} & $\begin{array}{l}\text { Green IT frame- } \\
\text { work for greening } \\
\text { data centers [31] }\end{array}$ & \begin{tabular}{|l|} 
Sustainable ICT \\
Capability Maturi- \\
ty Framework [6]
\end{tabular} & \begin{tabular}{|l} 
Envirability \\
maturity \\
framework \\
{$[29]$} \\
\end{tabular} \\
\hline \multicolumn{7}{|l|}{ General/business issues } \\
\hline Green ICT strategy & & $\begin{array}{l}\text { Green Business } \\
\text { and IS Strategy \& } \\
\text { Business mod- } \\
\text { el/Online chan- } \\
\text { nels }\end{array}$ & $\begin{array}{l}\text { Green IT } \\
\text { Strategies and } \\
\text { policies }\end{array}$ & & $\begin{array}{l}\text { Strategy and } \\
\text { planning }\end{array}$ & \multirow[t]{2}{*}{$\begin{array}{l}\text { Governance \& } \\
\text { compliance }\end{array}$} \\
\hline $\begin{array}{l}\text { Governance of ICT } \\
\text { services }\end{array}$ & Governance & $\begin{array}{l}\text { Organisational } \\
\text { Governance }\end{array}$ & & & Corporate policies & \\
\hline $\begin{array}{l}\text { Green ICT procure- } \\
\text { ment }\end{array}$ & \begin{tabular}{|l|} 
Attitude, Policy, \\
Practice
\end{tabular} & $\begin{array}{l}\text { Procurement/IT } \\
\text { Outsourcing } \\
\end{array}$ & & Procurement & \multirow[b]{2}{*}{$\begin{array}{l}\text { Operations and life } \\
\text { cycle }\end{array}$} & Procurement \\
\hline E-waste Policy & $\begin{array}{l}\text { Attitude, Policy, } \\
\text { Practice, Tech- } \\
\text { nology }\end{array}$ & $\begin{array}{l}\text { Waste/disposal } \\
\text { recycling }\end{array}$ & $\begin{array}{l}\text { Green disposal } \\
\text { of IT systems }\end{array}$ & $\begin{array}{l}\text { Recycle and dispos- } \\
\text { al }\end{array}$ & & $\begin{array}{l}\text { Disposal, } \\
\text { recycle \& } \\
\text { reuse }\end{array}$ \\
\hline $\begin{array}{l}\text { Green ICT in } \\
\text { Information Man- } \\
\text { agement and Archi- } \\
\text { tecture }\end{array}$ & & & & & $\begin{array}{l}\text { ICT enabled busi- } \\
\text { ness processes\& } \\
\text { Performance and } \\
\text { reporting } \\
\end{array}$ & \\
\hline $\begin{array}{l}\text { Community Collab- } \\
\text { oration }\end{array}$ & & & & & External compliance & \\
\hline $\begin{array}{l}\text { Green ICT supply } \\
\text { Chain Management }\end{array}$ & Policy & $\begin{array}{l}\text { Supply Chain } \\
\text { Management }\end{array}$ & & & $\begin{array}{l}\text { ICT enabled busi- } \\
\text { ness processes }\end{array}$ & $\begin{array}{l}\text { Business } \\
\text { process } \\
\text { management } \\
\end{array}$ \\
\hline \multicolumn{7}{|c|}{ Greening of ICT (Green IT) } \\
\hline Housing & Attitude & $\begin{array}{l}\text { Buildings man- } \\
\text { agement systems }\end{array}$ & \multirow{6}{*}{$\begin{array}{l}\text { Green use of } \\
\text { IT systems }\end{array}$} & & \multirow{6}{*}{$\begin{array}{l}\text { Operations \& life } \\
\text { cycle, Performance } \\
\& \text { reporting }\end{array}$} & Data center \\
\hline $\begin{array}{l}\text { Computing Infra- } \\
\text { structure }\end{array}$ & \begin{tabular}{|l} 
Policy, Practice, \\
Technology
\end{tabular} & \multirow{3}{*}{$\begin{array}{l}\text { Data center \& IT } \\
\text { infrastructure }\end{array}$} & & & & environmentals \\
\hline $\begin{array}{l}\text { Network Infrastruc- } \\
\text { ture }\end{array}$ & \begin{tabular}{|l|} 
Attitude, Practice, \\
Technology
\end{tabular} & & & $\begin{array}{l}\text { Revamp architec- } \\
\text { ture \& infrastructure }\end{array}$ & & $\begin{array}{l}\text { Networking \& } \\
\text { communica- } \\
\text { tions } \\
\end{array}$ \\
\hline $\begin{array}{l}\text { Storage infrastruc- } \\
\text { ture }\end{array}$ & $\begin{array}{l}\text { Attitude, Practice, } \\
\text { Technology }\end{array}$ & & & & & $\begin{array}{l}\begin{array}{l}\text { Data center } \\
\text { environmentals }\end{array} \\
\end{array}$ \\
\hline $\begin{array}{l}\text { End user ICT } \\
\text { Equipment (PC's, } \\
\text { printers, etc.) }\end{array}$ & $\begin{array}{l}\text { Policy, Technol- } \\
\text { ogy }\end{array}$ & Front Office IT & & & & $\begin{array}{l}\text { End User } \\
\text { Computing }\end{array}$ \\
\hline $\begin{array}{l}\text { Software and ICT } \\
\text { services }\end{array}$ & Technology & $\begin{array}{l}\text { Procurement/IT } \\
\text { Outsourcing }\end{array}$ & & \begin{tabular}{|l|} 
Identify virtualiza- \\
tion \& cloud \\
computing, Imple- \\
ment Virtualization \\
\& Cloud Computing \\
with Outsourcing \\
\end{tabular} & & $\begin{array}{l}\text { Outsourcing \& } \\
\text { Cloud }\end{array}$ \\
\hline \multicolumn{7}{|c|}{ Greening of operations with ICT (Green IS) } \\
\hline $\begin{array}{l}\text { Travel reductions } \\
\text { with ICT }\end{array}$ & & $\begin{array}{l}\text { Teleconferencing } \\
\text { \& teleworking }\end{array}$ & \multirow{4}{*}{$\begin{array}{l}\text { Green use of } \\
\text { IT systems }\end{array}$} & & \multirow[b]{3}{*}{$\begin{array}{l}\text { ICT enabled busi- } \\
\text { ness processes }\end{array}$} & $\begin{array}{l}\text { Teleworking \& } \\
\text { Collaboration } \\
\end{array}$ \\
\hline \multicolumn{7}{|l|}{$\begin{array}{l}\text { Area reductions with } \\
\text { ICT }\end{array}$} \\
\hline $\begin{array}{l}\text { Energy reductions } \\
\text { with ICT }\end{array}$ & $\begin{array}{l}\text { Attitude, Policy, } \\
\text { Technology }\end{array}$ & $\begin{array}{l}\text { Environmental } \\
\text { management } \\
\text { system } \\
\end{array}$ & & & & \\
\hline $\begin{array}{l}\text { Paper reductions } \\
\text { with ICT }\end{array}$ & $\begin{array}{l}\text { Practice, Tech- } \\
\text { nology }\end{array}$ & $\begin{array}{l}\text { Office processes } \\
\& \text { printing }\end{array}$ & & & & $\begin{array}{l}\text { Printing \& } \\
\text { Consumables } \\
\end{array}$ \\
\hline $\begin{array}{l}\text { Feedback and } \\
\text { decision support }\end{array}$ & $\begin{array}{l}\text { Attitude, Policy, } \\
\text { Practice }\end{array}$ & $\begin{array}{l}\text { Buildings man- } \\
\text { agement system } \\
\& \text { Prod- } \\
\text { uct/Service } \\
\text { operations }\end{array}$ & & Analysis phase & $\begin{array}{l}\text { Performance and } \\
\text { reporting }\end{array}$ & Metrics \\
\hline \multicolumn{7}{|c|}{ Greening of primary processes in higher education with ICT (Sector-specific constructs in SGIMM, sector-independent in the rest) } \\
\hline Education & \multirow{5}{*}{ Policy, Practice } & \multirow{5}{*}{$\begin{array}{l}\text { Product/service } \\
\text { processes }\end{array}$} & \multirow{5}{*}{$\begin{array}{l}\text { Green use of } \\
\text { IT systems }\end{array}$} & & \multirow{5}{*}{$\begin{array}{l}\text { ICT enabled busi- } \\
\text { ness processes }\end{array}$} & \multirow{5}{*}{$\begin{array}{l}\text { Business } \\
\text { process } \\
\text { management \& } \\
\text { Business } \\
\text { Applications }\end{array}$} \\
\hline Education support & & & & & & \\
\hline Research & & & & & & \\
\hline Research Support & & & & & & \\
\hline $\begin{array}{l}\text { Valorisation } \\
\text { Information Access }\end{array}$ & & & & & & \\
\hline
\end{tabular}




\begin{tabular}{|c|c|c|c|c|c|c|}
\hline $\begin{array}{l}\text { SURF Green ICT } \\
\text { Maturity Model } \\
{[12]}\end{array}$ & $\begin{array}{l}\text { G-Readiness } \\
\text { framework [24] }\end{array}$ & $\begin{array}{l}\text { Practice orient- } \\
\text { ed Green IS } \\
\text { Framework [3] }\end{array}$ & $\begin{array}{l}\text { Holistic } \\
\text { approach to } \\
\text { Green IT [26] }\end{array}$ & $\begin{array}{l}\text { Green IT frame- } \\
\text { work for greening } \\
\text { data centers [31] }\end{array}$ & $\begin{array}{l}\text { Sustainable ICT } \\
\text { Capability Maturi- } \\
\text { ty Framework [6] }\end{array}$ & \begin{tabular}{|l|} 
Envirability \\
maturity \\
framework \\
{$[29]$}
\end{tabular} \\
\hline \multicolumn{7}{|c|}{ NON-MATCHING CONSTRUCTS (i.e. constructs missing in SGIMM, but added in its column to facilitate the mapping) } \\
\hline People & & People & \multirow{4}{*}{ 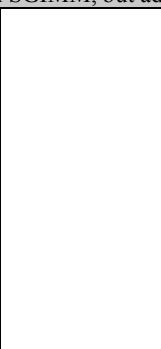 } & 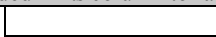 & People and culture & \\
\hline $\begin{array}{l}\text { GHG emissions } \\
\text { management }\end{array}$ & $\begin{array}{l}\text { Attitude: GHG } \\
\text { emissions }\end{array}$ & & & $\begin{array}{l}\text { Governance \& } \\
\text { Compliance to } \\
\text { lower CO2, Carbon } \\
\text { Emission Manage- } \\
\text { ment, Measure CO2 } \\
\text { Emissions }\end{array}$ & & $\begin{array}{l}\text { Carbon emis } \\
\text { sion manage- } \\
\text { ment }\end{array}$ \\
\hline $\begin{array}{l}\text { Green energy } \\
\text { sources }\end{array}$ & $\begin{array}{l}\text { Policy: green } \\
\text { sources of energy }\end{array}$ & Green energy & & & & \\
\hline $\begin{array}{l}\text { Extra waste caused } \\
\text { by IT }\end{array}$ & $\begin{array}{l}\text { Practice: extra } \\
\text { waste (paper, } \\
\text { batteries, etc.) }\end{array}$ & $\begin{array}{l}\text { Smaller product } \\
\text { \& packaging, } \\
\text { packaging }\end{array}$ & & & & \\
\hline $\begin{array}{l}\text { Green standards and } \\
\text { metrics }\end{array}$ & & Energy standards & $\begin{array}{l}\text { Green stand- } \\
\text { ards and } \\
\text { metrics }\end{array}$ & \begin{tabular}{|l|} 
Identify green \\
metrics \& set \\
benchmarks \\
\end{tabular} & & \\
\hline Green production & & & $\begin{array}{l}\text { Green manu- } \\
\text { facturing of IT } \\
\text { systems }\end{array}$ & & & \\
\hline Green design & & & $\begin{array}{l}\text { Green design } \\
\text { of IT systems }\end{array}$ & & & \\
\hline Green data centres & $\begin{array}{l}\text { Policy: green data } \\
\text { center }\end{array}$ & & & & & \\
\hline Shorten refreshment & $\begin{array}{l}\text { Practice: shorten } \\
\text { refreshment of } \\
\text { equipment to } \\
\text { increase its } \\
\text { efficiency }\end{array}$ & & & & & \\
\hline $\begin{array}{l}\text { Corporate social } \\
\text { responsibility }\end{array}$ & Policy: CSR & & & & & \\
\hline $\begin{array}{l}\text { Data center specific } \\
\text { technologies }\end{array}$ & & & & $\begin{array}{l}\text { Identify virtualiza- } \\
\text { tion \& cloud } \\
\text { computing }\end{array}$ & & \\
\hline $\begin{array}{l}\text { Data centre catego- } \\
\text { risation }\end{array}$ & & & & $\begin{array}{l}\text { Categorize data } \\
\text { centers }\end{array}$ & & \\
\hline $\begin{array}{l}\text { Software architec- } \\
\text { ture }\end{array}$ & & & & & & \begin{tabular}{|l}
$\begin{array}{l}\text { Software } \\
\text { architecture }\end{array}$ \\
\end{tabular} \\
\hline Planning & & & & Planning phase & & \\
\hline Equipment for waste & & Equipment & & & & \\
\hline Product take-back & & $\begin{array}{l}\text { Product-take- } \\
\text { back }\end{array}$ & & & & \\
\hline \begin{tabular}{|l}
$\begin{array}{l}\text { Social clauses } \\
\text { (SOMO) }\end{array}$ \\
\end{tabular} & & & & & & \\
\hline
\end{tabular}

\section{Extension of SGIMM and auditing project}

The ITS department provides ICT services, tools and infra-structure to support Utrecht University students, lecturers, researchers and administrative staff in their studies and work. The department had a preference for using the SGIMM during the auditing project. Since they also expected us to audit as many aspects of the organisation as possible, we decided to extend SGIMM with additional constructs identified during the comparison.

\subsection{Extension of SGIMM maturity model}

After the comparison, 17 constructs were found missing in SGIMM. These are presented in italics, at the bottom of 0 Namely, People, GHG emissions management, Green energy sources, Extra waste caused by IT, Green standards and metrics, Green production, Green design, Green data centres, Shorten refreshment, Corporate social responsibility, Data centre-specific technologies, 
Data centre categorisation, Software architecture, Planning, Equipment for waste, Product takeback. Additionally, we also considered the inclusion of Social clauses in ICT procurement contracts, after a conversation with a consultant from the Centre for Research on Multinational Corporations (SOMO).

After consultation with the members of the ITS department that were actively involved in the auditing project, we decided to extend the SGIMM with the constructs People and Extra waste caused by IT, not as a permanent addition to the maturity model, but to increase the value of the model as a tool for auditing the ITS department. The People construct was refined into the several aspects mentioned by the Practice-Oriented Green IS Framework; namely, Training and participation, Commitment mechanisms, Internal communication, Incentives/recognition, Evaluation/reporting, Roles/activities. Additionally, the following ITS-specific constructs were added: ITS product matrix and leverage products, (the extent to which the department can switch to a different supplier for products that are important but still not financially risky, in an attempt to increase the product sustainability), The mission of ITS (how the department could increase the sustainability in each of the dimensions of their mission; namely, customer-focused orientation, management and innovation, reliability and quality, guarantee the safety of university data), Sustainability in standard meetings (the degree to which sustainability is a regular topic being discussed during standard meetings at the department), Including sustainability issues aimed at optimising business processes related to ICT (whether users are involved during change management projects in the department, whether sustainability is a key factor during the standardisation of ITS processes, whether the ITS department manages redundant ICT or data properly in an attempt to save resources), Sustainable procurement (the extent to which the department fosters and performs ethical procurement practices).

Furthermore, based on the analysis of the other maturity models, the following changes to the SGIMM were planned:

- A section in the Excel-based tool explaining the constructs in more detail, since some terms are quite general and could possibly be subject to subjective interpretation.

- A section that explains the importance of Green standards and metrics. The Envirability framework provided the foundation for this addition. However, adding metrics in each separate construct of the SGIMM, in its current form (an Excel sheet with all information on a few sheets), would be unclear and redundant, so we opted for a separate section.

\subsection{Conduction of the ICT sustainability auditing}

The ITS department advises the Executive Board on investment in the architecture and use of ICT systems. It also formulates the framework of corporate ICT policy and is responsible for the program management of ICT investment and innovation. Also, the ITS department provides basic ICT services for staff, students and visitors of Utrecht University; management of university network infrastructure and finally, management of ICT systems for the benefit of operational management. Many of the department business functions are closely related to the constructs of SGIMM (e.g. Education support, ICT management), whereas other functions are less coupled (e.g. Scheduling).

The audit was conducted during a single collaborative workshop with three employees at the ITS department. It is also out of the scope of this paper to present the actual scores of the auditing process, which can be found in the first author's MSc thesis [17]. Nonetheless, it is worth mentioning that the scores were not high, and this was perceived by the assessment team as a wake-up call for the department. The team also defined the following improvement actions:

- Increase the sustainable procurement practices: Currently, sustainability criteria are applied while procuring leverage products, but the department sees opportunity to extend this to other hardware and software products. 
- Run Green ICT awareness campaigns: The intention is to increase the perception of the importance of sustainability within the whole range of business functions of the ITS department.

- Propose student projects in the People domain: Offer students the possibility to conduct voluntary and ECTS-rewarded projects to explore how to improve the maturity of the constructs of the People domain.

The team considered these improvement actions as either low-hanging fruits (e.g. proposing student projects) of critical to enable more improvements in the future (e.g. raising awareness). A second auditing will be undertaken once some of these actions have been successfully executed. The department hopes to have increased the maturity by then.

\section{Discussion of the results and validity threats}

The analysis of existing Green ICT models has allowed us to gain knowledge on the different approaches that exist to define frameworks and maturity models in this area. We have extracted relevant information from each model to better understand them. They all have merit and it was never our intention to champion any of them, but just to understand what constructs they cover. The comparison matrix shows that no model is all-encompassing. Depending on the task for which the model is going to be used, a different model can be more convenient. Our intention was to later use SGIMM to conduct a sustainability audit, so we took the opportunity to extend it with constructs that were missing and the ITS department found relevant.

During the discussions on extending the SGIMM, we noticed that refining the constructs of the model or adding new ones made it more comprehensive but, at the same time, more complex and time-consuming. In some occasions, we reverted the change or implemented it differently (e.g. adding a separate and optional explanation section). This calls for a careful analysis of the added value of each extension proposal and its trade-offs. This analysis can be done involving other researchers and organisational stakeholders. In the end, the additions to the SGIMM were perceived as valuable by the ITS Department stakeholders, especially the People construct, coming from [3] and [6].

The auditing itself was considered successful in the sense that it allowed assessing the current maturity level of the department. The constructs that we added to extend SGIMM were not only deemed useful by the assessment team, but they actually led to the definition of the three improvement actions.

The main threat to the validity of the results is the inherent subjectivity of qualitative analysis. The mapping of constructs was carried out by one researcher; the results were revised by two more researchers first and then by the whole team. This reduces the threat but, still, this mapping is subject to imperfections. We acknowledge this fact but nonetheless consider that the knowledge it provides is valuable. It can trigger discussions in Green ICT community about what constructs are relevant, and whether they are sufficiently understood by organisations.

Another important remark is that we have kept the analysis at the level of construct existence. But it is also important how developed the constructs are; that is, the knowledge and collection of best practices that are included in each construct. We did not deepen into this and further research is surely required.

We do not assume that merging the constructs of all existing maturity models will produce the perfect suite of constructs. Constructs would still be missing and, since there is a vibrant community investigating on Green ICT, the constructs are subject to frequent evolution. Also, there might be other models in the body of knowledge that were not retrieved by our literature review and would deserve being considered. 
Last but not least, sustainability is a complex notion. The same way any decision incurs in trade-offs in the environmental, economic, social, individual and technical dimensions, organisational strategies and improvement actions related to a given construct of the maturity models will equally affect other constructs. That is, it is unlikely that one organisation can unlimitedly increase the maturity in one construct without compromising other constructs. This factor should be taken into account in future work.

\section{Conclusions and future research}

In this paper, we have explored the maturity models (and conceptual frameworks) in the area of Green ICT. We have also applied the gathered knowledge to extend a maturity model with the intention to apply it during an ICT sustainability auditing.

We consider that the research method we have applied can be used as a method to comparatively analyse maturity models of other areas and, when needed, extend or improve a given maturity model. But it is first required to apply it to other areas in order to ascertain this. Besides being applied by researchers in search of knowledge, it could potentially be applied by organisations that wish to select and adapt a maturity model for practical purposes. However, we should first investigate whether the effort of applying such a thorough comparison method would cost-effective for organisations. We plan to address this in future research endeavours

\section{Acknowledgements}

We are grateful to the employees of the ITS department of Utrecht University for their participation in interviews and their advice. Special thanks go to Jeroen Schipper and Aloysia Kluck, for triggering the project and for their valuable contribution. We also acknowledge Gisela ten Kate, from SOMO for her useful comments on responsible procurement. Lastly, we appreciate the support and encouragement received from Anjelle Rademakers, Emily Swaddle, Roy van den Berg and Briede van Bemmelen, from Green Office Utrecht.

\section{References}

[1] Andreopoulou, Z. (2012). Green informatics: ICT for green and sustainability. Agrárinformatika/Journal of Agricultural Informatics, 3(2), 1-8.

[2] Boudreau, M., Chen, A., \& Huber, M. (2008). Green IS: Building sustainable business practices. In R. T. Watson (Ed.), Information systems: A global text (pp. 1-17). Athens: GA: Global Text Project.

[3] Butler, T. (2011). Towards a practice-oriented green IS framework. Paper presented at the Ecis,

[4] Curry, E. \& Donnellan, B. (2012) Understanding the maturity of sustainable ICT. Green Business Process Management. Springer, 203-216.

[5] De Bruin, T., Freeze, R., Kaulkarni, U., \& Rosemann, M. (2005). Understanding the main phases of developing a maturity assessment model.

[6] Donnellan, B., Sheridan, C., \& Curry, E. (2011). A capability maturity framework for sustainable information and communication technology. IT Professional, 13(1), 33-40. 
[7] Elliot, S., \& Binney, D. (2008). Environmentally sustainable ICT: Developing corporate capabilities and an industry-relevant IS research agenda. Paper presented at the 12th Pacific Asia Conference on Information Systems, Suzhou, China. 4-7.

[8] Elo, S., \& Kyngäs, H. (2008). The qualitative content analysis process. Journal of Advanced Nursing, 62(1), 107-115.

[9] Gottschalk, P. (2009) Maturity levels for interoperability in digital government. Government Information Quarterly, vol. 26, 75-81.

[10] Hankel, A. (2014). Understanding higher order impacts of green ICT. Paper presented at the 2nd ICT4S Conference, 385-391,

[11] Hankel, A., Heimeriks, G. \& Lago, P. (2016) Green ICT Assessment for Organisations. Journal of ICT Standardization 4(2), 87-110.

[12] Hankel, A., Oud, L., Saan, M., \& Lago, P. (2014). A maturity model for green ICT: The case of the SURF green ICT maturity model. EnviroInfo 2014, 33-40.

[13] Hilty, L. M. and B. Aebischer, Eds. (2015). ICT innovations for sustainability. Advances in Intelligent Systems and Computing. 2015, Springer.

[14] Humphrey, W. S. (1988). Characterizing the software process: A maturity framework. Software, IEEE, 5(2), 73-79.

[15] Jiankang, W., Jiuling, X., Qianwen, L., \& Kun, L. (2011). Knowledge management maturity models: A systemic comparison. 2011 International Conference on Information Management, Innovation Management and Industrial Engineering, Shenzen. , 3 606-609.

[16] Khoshgoftar, M., \& Osman, O. (2009). Comparison of maturity models. Paper presented at the Computer Science and Information Technology, 2009. ICCSIT 2009. 2nd IEEE International Conference On, Beijing. 297-301.

[17] Lautenschutz, D. (2016). Defining an auditing protocol to measure the maturity level of sustainable ICT in Utrecht University, MSc. Thesis at the Dept. of Information and Computing Sciences, https://dspace.library.uu.n/handle/1874/345809

[18] Lee, J., Kang, S., Lee, D., Ahn, Y., \& Park, A. B. (2009). Comparison of vPMM and BPMM. Paper presented at the Software Engineering, Artificial Intelligences, Networking and Parallel/Distributed Computing, 2009. SNPD'09. 10th ACIS International Conference On, 321326.

[19] Mettler, T. \& Rohner, P. (2009). Situational maturity models as instrumental artifacts for organizational design. 4th International Conference on Design Science Research in Information Systems and Technology (DESRIST 2009). Philadelphia, USA, ACM: 1-9.

[20] Mettler, T. (2011). Maturity assessment models: A design science research approach. International Journal of Society Systems Science, 3(1-2), 81-98.

[21] Molla, A., \& Cooper, V. (2010). Green IT readiness: A framework and preliminary proof of concept. Australasian Journal of Information Systems, 16(2)

[22] Molla, A., Cooper, V. A., \& Pittayachawan, S. (2009). IT and eco-sustainability: Developing and validating a green IT readiness model. ICIS 2009 Proceedings, Paper 141.

[23] Molla, A., Cooper, V., Corbitt, B., Deng, H., Peszynski, K., Pittayachawan, S., \& Teoh, S. Y. (2008). E-readiness to G-readiness: Developing a green information technology readiness framework. ACIS 2008 Proceedings, 35.

[24] Molla, A., Cooper, V., \& Pittayachawan, S. (2011). The green IT readiness (G-readiness) of organizations: An exploratory analysis of a construct and instrument. Communications of the Association for Information Systems, 29(1), 67-96.

[25] Murugesan, S. (2008). Harnessing green IT: Principles and practices. IT Professional, 10(1), 24-33. 
[26] Murugesan, S., \& Gangadharan, G. (2012). Green IT: An overview. In S. Murugesan, \& G. Gan-gadharan (Eds.), Harnessing green IT: Principles and practices (pp. 25-43). Wiley, Chichester: Wiley-IEEE Press.

[27] Pahuja, S. (2013) Environmental audit. Encyclopedia of Corporate Social Responsibility, S.O. Idowu, N. Capaldi, L. Zu, and A.D. Gupta (Eds.): Springer, 2013, pp. 969-979.

[28] Paulk, M.C., Curtis, B., Chrissis, M.B. and Weber, C.V. (1993) Capability maturity model, version 1.1. IEEE Software 10 (4,), 18-27.

[29] Philipson, G. (2010). A comprehensive and practical green ICT framework. In B. Unhelkar (Ed.), Handbook of research on green ICT: Technology, business and social perspectives: Technology, business and social perspectives (pp. 131-145). New York: Hershey.

[30] Pulparambil, S., \& Baghdadi, Y. (2015). A comparison framework for SOA maturity models. Paper presented at the 2015 IEEE International Conference on Smart City/SocialCom/SustainCom (SmartCity), 1102-1107.

[31] Uddin, M., \& Rahman, A. A. (2012). Energy efficiency and low carbon enabler green IT framework for data centers considering green metrics. Renewable and Sustainable Energy Reviews, 16(6), 4078-4094.

[32] van de Weerd, I., \& Brinkkemper, S. (2008). Meta-modeling for situational analysis and design methods. Handbook of Research on Modern Systems Analysis and Design Technologies and Applications, 35

[33] van Steenbergen, M., Bos, R., Brinkkemper, S., van de Weerd, I., \& Bekkers, W. (2013). Improving IS functions step by step: The use of focus area maturity models. Scandinavian Journal of Information Systems, 25(2), 35-56.

[34] Wendler, R. (2012). The maturity of maturity model research: A systematic mapping study. Information and Software Technology, 54(12), 1317-1339.

[35] Wieringa, R. J. (2014). Design science methodology for information systems and software engineering. Berlin: Springer. 